\title{
UPAYA PENINGKATAN KINERJA GURU \\ MELALUI TEKNIK LESSON STUDY SECARA \\ KOLABORATIF DAN RUTIN DI TK NURUSSIBYAN KOTA JAMBI
}

\author{
JAMILAH \\ TK Nurussibyan Kota Jambi \\ suryani.wan@yahoo.com
}

\begin{abstract}
ABSTRAK
Tuntutan masyarakat saat ini adalah pendidikan yang bermutu, sekolah dituntut memperbaiki atau meningkatkan pencitraan publik sehingga masyarakat yakin bahwa sekolah tersebut layak menjadi pilihan putra-putrinya. Lesson Study dengan karakteristiknya nampaknya dapat digunakan sebagai salah satu alternatif untuk mengatasi masalah tersebut sehingga pencitraan publik sekolah meningkat.

Memang Lesson Study banyak menekankan pada pembelajaran di kelas namun dampak kegiatan ini bisa pada aspek yang lain misal: peningkatan sarana pembelajaran, inovasi sekolah, perubahan visi dan misi sekolah, motivasi guru dan pimpinan sekolah, serta muncul aktivitas ekstrakurikuler dan lain-lain.

Lesson Study berbasis sekolah yang dilakukan secara rutin akan muncul inovasi pada sekolah sehingga dapat digunakan sebagai upaya memperbaiki citra publik sekolah, kegiatan bisa berlangsung dengan baik perlu adanya komitmen kepala sekolah dan kemauan guru untuk memperbaiki diri.
\end{abstract}

\section{Kata kunci: Kinerja Guru, Teknik Pembelajaran, Teknik Lesson Study.}

\section{A. PENDAHULUAN}

\section{Latar Belakang}

Salah satu persoalan pendidikan yang sedang dihadapi bangsa kita adalah persoalan mutu pendidikan pada setiap jenjang dan satuan pendidikan. Berbagai usaha telah dilakukan untuk meningkatkan mutu pendidikan nasional, antara lain melalui berbagai pelatihan dan peningkatan kompetensi guru, pengadaan buku dan alat pelajaran, perbaikan sarana dan prasarana pendidikan, dan meningkatkan mutu manajemen sekolah. Namun demikian, indikator mutu pendidikan belum menunjukkan peningkatan yang berarti. Sebagian sekolah, terutama di kota-kota, menunjukkan peningkatan mutu pendidikan yang cukup menggembirakan, sebagian besar lainnya masih memprihatinkan. 
Dalam upaya meningkatkan mutu pendidikan nasional, pemerintah khususnya melalui Departemen Pendidikan Nasional terus menerus berupaya melakukan berbagai perubahan dan pembaharuan sistem pendidikan kita. Salah satu upaya yang sudah dan sedang dilakukan, yaitu berkaitan dengan faktor guru. Lahirnya Undang-Undang No. 14 tahun 2005 tentang Guru dan Dosen dan Peraturan Pemerintah No. 19 Tahun 2005 tentang Standar Nasional Pendidikan, pada dasarnya merupakan kebijakan pemerintah yang di dalamnya memuat usaha pemerintah untuk menata dan memperbaiki mutu guru di Indonesia. Michael G. Fullan yang dikutip oleh Suyanto dan Djihad Hisyam (2000) mengemukakan bahwa "educational change depends on what teachers do and think...". Pendapat tersebut mengisyaratkan bahwa perubahan dan pembaharuan sistem pendidikan sangat bergantung pada "what teachers do and think", atau dengan kata lain bergantung pada penguasaan kompetensi guru.

Jika kita amati lebih jauh tentang realita kompetensi guru saat ini agaknya masih beragam. Sudarwan Danim (2002) mengungkapkan bahwa salah satu ciri krisis pendidikan di Indonesia adalah guru belum mampu menunjukkan kinerja (work performance) yang memadai. Hal ini menunjukkan bahwa kinerja guru belum sepenuhnya ditopang oleh derajat penguasaan kompetensi yang memadai, oleh karena itu perlu adanya upaya yang komprehensif guna meningkatkan kompetensi guru.

Berdasarkan masalah di atas, maka berbagai pihak mempertanyakan apa yang salah dalam penyelenggaraan pendidikan kita? Kurangnya pemahaman guru akan tugasnya sebagai agen pembelajaran, merupakan salah satu faktor rendahnya mutu pembelajaran. Guru sebagai agen pembelajaran harus memiliki beberapa kompetensi diantaranya adalah kompetensi kepribadian, kompetensi pedagogik, kompetensi profesional, dan kompetensi sosial. Apabila guru mampu menguasai kompetensi tersebut maka mutu pendidikan akan meningkat.

Dari uraian di atas, penulis selaku kepala sekolah melakukan terobosan untuk menyikapi sekaligus memperbaiki pola-pola pemikiran yang salah dengan memberikan pengarahan/ pembinaan guru berbasis sekolah yang 
dinamakan dengan (Lesson Study) secara kolaboratif dan berkelanjutan berlandaskan prinsip-prinsip kolegalitas dan mutual learning untuk membangun komunitas belajar, untuk membekali guru dalam melaksanakan tugasnya sebagai agen pembelajaran. Kata kuncinya adalah "rutinitas" penulis mempunyai keyakinan bahwa dengan pengarahan secara rutin, terprogram dengan baik dan kontrol terhadap persiapan guru sebelum melaksanakan tugas mengajar di kelas maka akan terbentuk tenaga pendidik yang produktif/ profesional dan mampu meningkatkan mutu pembelajaran. Memang, dalam awal-awal pelaksanaan program ini ada beberapa diantara guru yang menunjukkan sikap acuh tak acuh, tetapi dengan kesabaran dan ketekunan akhirnya guru tersebut sangat antusias setelah merasakan dampak dan manfaat yang dapat dipetik dari pelaksanaan program tersebut.

Hubungan kepala sekolah dengan guru-guru harus baik, tanggung jawab, didasari dengan kejujuran, kesetiaan, keikhlasan dan kerjasama. Apabila diibaratkan dalam satu keluarga, maka hubungan Kepala Sekolah dengan guruguru lainnya harus beriangsung bagaikan hubungan satu saudara dengan saudara lainnya, dan hubungan kepala sekolah dengan siswa harus seperti hubungan ayah dengan anak.

Maka berdasarkan latar belakang tersebut penulis melakukan upaya perbaikan untuk meningkatkan mutu pembelajaran di Sekolah Taman Kanakkanak Nurussibyan Kecamatan Jambi Selatan Kota Jambi melalui Penelitian Tindakan Sekolah (PTS) dengan judul: "Upaya Peningkatan Kinerja Guru Melalui Teknik Lesson Study Secara Kolaboratif dan Rutin Di Taman Kanak-kanak Nurussibyan Kota Jambi"

\section{Rumusan Masalah}

Dalam Penelitian Tindakan Sekolah ini penulis merumuskan masalah sebagai berikut:

a. Bagaimana perencanaan guru dalam melaksanakan tugas mengajar agar mutu pembelajaran meningkat?

b. Bagaimana pemahaman guru terhadap tugasnya sebagai agen pembelajaran? 
c. Bagaimana guru menerapkan teknik praktek rencana pembelajaran di kelas untuk meningkatkan mutu pembelajaran?

d. Apakah tingkat kesadaran dan tanggung jawab guru sebagai pendidik sudah seimbang dengan tugas pokok dan fungsi yang dibebankan oleh pemerintah?

\section{Tujuan}

Secara khusus tujuan penelitian dirumuskan sebagai berikut:

a. Meningkatkan kesadaran dan tanggung jawab guru akan tugas pokok dan fungsinya yang dibebankan oleh orang tua, masyarakat dan pemerintah.

b. Menyusun dan mengevaluasi perencanaan guru dalarn melaksanakan tugas mengajar agar mutu pembelajaran meningkat.

c. Meningkatkan pemahaman guru terhadap tugasnya sebagai agen pembelajaran.

d. Membentuk dan menciptakan disiplin kerja serta iklim budaya kerja sekolah untuk meningkatkan mutu pembelajaran.

\section{Manfaat}

a. Bagi Guru

Memberikan keuntungan dan kesempatan kepada para guru untuk dapat:

- Memikirkan secara lebih teliti lagi tentang tujuan, materi tertentu yang akan dibelajarkan kepada siswa.

- Memikirkan secara mendalam tentang tujuan-tujuan pembelajaran untuk kepentingan masa depan siswa, misalnya tentang arti penting sebuah persahabatan, pengembangan perspektif dan cara berfikir siswa, serta kegandrungan siswa terhadap ilmu pengetahuan.

- Mengkaji tentang hal-hal terbaik yang dapat digunakan dalam pembelajaran melalui belajar dari para guru lain (peserta atau partisipan Lesson Study),

b. Manfaat bagi Sekolah

Penelitian ini diharapkan dapat memberikan umpan balik bagi pembinaan dan pengembangan kompetensi guru untuk meningkatkan mutu pembelajaran dan pendidikan. 
c. Manfaat Bagi Siswa

Siswa akan menikmati pembelajaran yang lebih tertib dan bermutu karena guru telah mempersiapkan segala sesuatunya dengan baik.

\section{B. Kajian Teoritis}

\section{Tugas Pokok Kepala Sekolah}

Tugas pokok Kepala Sekolah adalah merencanakan, melaksanakan program manajamen sekolah termasuk memantau, menilai mensupervisi, membina, dan melaporkan terhadap kinerja guru dalam pembelajaran, kinerja sekolah dalam mengelola pendidikan. Sofyan Salim (2007) tugas yang harus dilakukan Kepala Sekolah adalah melakukan pembinaan pengembangan kualitas sekolah, kinerja sekolah, kinerja guru dan kinerja seluruh staf sekolah. Kepala sekolah managerial pada dasarnya memberikan pembinaan, penilaian dan bantuan/bimbingan mulai dari rencana program, proses dan sampai dengan hasil.

Fungsi Kepala Sekolah adalah sebagai mitra guru, pembaru (inovator), penyuluh (konselor), pendorong (motivator), kerjasama (kolabolator), penilaian (asesor), konsultan didalam melaksanakan tugas pokok dan tanggung jawabnya terhadap kinerja guru dalam pembelajaran dan kinerja kepala sekolah dalam mengelola pendidikan.

Salim (2007) mengemukakan Kepala Sekolah satuan pendidikan melaksanakan fungsi-fungsi supervisi, baik supervisi akademik maupun supervisi manajerial. Adapun sasaran supervisi akademik antara lain membantu guru dalam merencanakan kegiatan pembelajaran dan atau bimbingan, mengembangkan interaksi pembelajaran (metode, strategi, teknik, model, pendekatan dan lain-lain) yang tepat guna.

\section{Peran Kepala Sekolah}

Agar proses pendidikan dapat berjalan efektif dan efisien, guru dituntut memiliki kompetensi yang memadai, baik dari segi jenis maupun isinya. Namun, jika kita selami lebih dalam lagi tentang isi yang terkandung dari setiap 
jenis kompetensi, sebagaimana disampaikan oleh para ahli maupun dalam perspektif kebijakan pemerintah, kiranya untuk menjadi guru yang kompeten bukan sesuatu yang sederhana. Untuk mewujudkan dan meningkatkan kompetensi guru diperlukan upaya yang sungguh-sungguh dan komprehensif.

Salah satu upaya yang dapat dilakukan adalah melalui optimalisasi peran kepala sekolah. Idochi Anwar dan Yayat Hidayat Amir (2000) mengemukakan bahwa "kepala sekolah sebagai pengelola memiliki tugas mengembangkan kinerja personel, terutama meningkatkan kompetensi profesional guru." Dalam perspektif kebijakan pendidikan nasional (Depdiknas, 2006), terdapat tujuh peran utama kepala sekolah yaitu, sebagai: (1) educator (pendidik); (2) manager; (3) administrator; (4) supervisor (penyelia); (5) leader (pemimpin); (6) pencipta iklim kerja; dan (7) wirausahawan.

Merujuk kepada tujuh peran kepala sekolah sebagaimana disampaikan oleh Depdiknas di atas, di bawah ini akan diuraikan secara ringkas hubungan antara peran kepala sekolah dengan peningkatan kompetensi guru.

a. Kepala sekolah sebagai educator (pendidik)

Kegiatan belajar mengajar merupakan inti dari proses pendidikan dan guru merupakan pelaksana dan pengembang utama kurikulum di sekolah. Kepala sekolah yang menunjukkan komitmen tinggi dan fokus terhadap pengembangan kurikulum dan kegiatan belajar mengajar disekolahnya tentu saja akan sangat memperhatikan tingkat kompetensi yang dimiliki gurunya, sekaligus juga akan senantiasa berusaha memfasilitasi dan mendorong agar para guru dapat secara terus menerus meningkatkan kompetensinya, sehingga kegiatan belajar mengajar dapat berjalan efektif dan efisien.

b. Kepala sekolah sebagai manager

Dalam mengelola tenaga kependidikan, salah satu tugas yang harus dilakukan kepala sekolah adalah melaksanakan kegiatan pemeliharaan dan pengembangan profesi para guru. Dalam hal ini, kepala sekolah seyogyanya dapat memfasiltasi dan memberikan kesempatan yang luas kepada para guru untuk dapat melaksanakan kegiatan pengembangan profesi melalui berbagai kegiatan pendidikan dan pelatihan, baik yang dilaksanakan di sekolah, seperti: 
MGMP/MGP tingkat sekolah, in house training, diskusi profesional dan sebagainya, atau melalui kegiatan pendidikan dan pelatihan di luar sekolah, seperti: kesempatan melanjutkan pendidikan atau mengikuti berbagai kegiatan pelatihan yang diselenggarakan pihak lain.

c. Kepala sekolah sebagai administrator

Khususnya berkenaan dengan pengelolaan keuangan, bahwa untuk tercapainya peningkatan kompetensi guru tidak lepas dari faktor biaya. Seberapa besar sekolah dapat mengalokasikan anggaran peningkatan kompetensi guru tentunya akan mempengaruhi terhadap tingkat kompetensi para gurunya. Oleh karena itu kepala sekolah seyogyanya dapat mengalokasikan anggaran yang memadai bagi upaya peningkatan kompetensi guru.

d. Kepala sekolah sebagai supervisor

Untuk mengetahui sejauh mana guru mampu melaksanakan pembelajaran, secara berkala kepala sekolah perlu melaksanakan kegiatan supervisi, yang dapat dilakukan melalui kegiatan kunjungan kelas untuk mengamati proses pembelajaran secara langsung, terutama dalam pemilihan dan penggunaan metode, media yang digunakan dan keterlibatan siswa dalam proses pembelajaran (E. Mulyasa, 2004). Dari hasil supervisi ini, dapat diketahui kelemahan sekaligus keunggulan guru dalam melaksanakan pembelajaran, tingkat penguasaan kompetensi guru yang bersangkutan, selanjutnya diupayakan solusi, pembinaan dan tindak lanjut tertentu sehingga guru dapat memperbaiki kekurangan yang ada sekaligus mempertahankan keunggulannya dalam melaksanakan pembelajaran.

e. Kepala sekelah sebagai leader (pemimpin)

Dalam teori kepemimpinan setidaknya kita mengenal dua gaya kepemimpinan yaitu kepemimpinan yang berorientasi pada tugas dan kepemimpinan yang berorientasi pada manusia. Dalam rangka meningkatkan kompetensi guru, seorang kepala sekolah dapat menerapkan kedua gaya kepemimpinan tersebut secara tepat dan fleksibel, disesuaikan dengan kondisi dan kebutuhan yang ada. 
Kepemimpinan seseorang sangat berkaitan dengan kepribadian dan kepribadian kepala sekolah sebagai pemimpin akan tercermin dalam sifat-sifat sebagai berikut: (1) jujur; (2) percaya diri; (3) tanggung jawab; (4) berani mengambil resiko dan keputusan; (5) berjiwa besar; (6) emosi yang stabil, dan teladan (E. Mulyasa, 2003).

\section{Lesson Study Dalam Kegiatan Pembelajaran}

Lesson Study merupakan model pembinaan profesi pendidik melalui pengkajian pembelajaran secara kolaboratif dan berkelanjutan berlandaskan prinsip-prinsip kolegalitas dan mutual learning untuk membangun komunitas belajar. Lesson Study adalah program yang diterapkan oleh SISTTEMS, (Strengthening In-Service Teacher Training of Mathematics and Science Education at Junior Secondary Level) yaitu bentuk kerjasama antara JICA (Japan International Cooperation Agency) dan MONE / Depdiknas (Ministry of National Education / Departemen Pendidikan Nasional) Indonesia.

Lesson Study bukan merupakan metoda atau strategi pembelajaran tetapi kegiatan yang dapat menerapkan berbagai metoda dan strategi pembelajaran yang sesuai dengan situasi, kondisi, kemampuan komunitas pembelajaran serta berbagai permasalahan yang dihadapi dalam kegiatan pembelajaran.

Slamet Mulyana (2007) mengemukakan tiga tahapan dalam Lesson Study, yaitu: (1) Perencanaan (Plan); (2) Pelaksanaan (Do) dan (3) Refleksi (See). Sedangkan Bill Cerbin dan Bryan Kopp dan University of Wisconsin mengetengahkan enam tahapan dalam Lesson Study, yaitu:

1. Form a Team: membentuk tim sebanyak 3-6 orang yang terdiri guru yang bersangkutan dan pihak-pihak lain yang kompeten serta memilki kepentingan dengan Lesson Study.

2. Develop Student Learning Goals: anggota tim mendiskusikan apa yang akan dibelajarkan kepada siswa sebagai hasil dari Lesson Study.

3. Plan the Research Lesson: guru-guru mendesain pembelajaran guna mencapai tujuan belajar dan mengantisipasi bagaimana para siswa akan merespons. 
4. Gather Evidence of Student Learning: salah seorang guru tim melaksanakan pembelajaran, sementara yang lainnya melakukan pengamatan, mengumpulkan bukti-bukti dari pembelajaran siswa.

5. Analyze Evidence of Learning: tim mendiskusikan hasil dan menilai kemajuan dalam pencapaian tujuan belajar siswa

6. Repeat the Process: kelompok merevisi pembelajaran, mengulang tahapantahapan mulai dari tahapan ke-2 sampai dengan tahapan ke-5 sebagaimana dikemukakan di atas, dan tim melakukan sharing atas temuan-temuan yang ada.

Di bawah ini akan diuraikan secara ringkas tentang empat tahapan dalam penyelengggaraan Lesson Study.

1. Tahapan Perencanaan (Plan)

Dalam tahap perencanaan, para guru yang tergabung dalam Lesson Study berkolaborasi untuk menyusun RPP yang mencerminkan pembelajaran yang berpusat pada siswa. Perencanaan diawali dengan kegiatan menganalisis kebutuhan dan permasalahan yang dihadapi dalam pembelajaran, seperti tentang: kompetensi dasar, cara membelajarkan siswa, mensiasati kekurangan fasilitas dan sarana belajar, dan sebagainya, sehingga dapat diketahui berbagai kondisi nyata yang akan digunakan untuk kepentingan pembelajaran. Selanjutnya, secara bersama-sama pula dicarikan solusi untuk memecahkan segala permasalahan ditemukan.

2. Tahapan Pelaksanaan (Do)

Pada tahapan yang kedua, terdapat dua kegiatan utama yaitu: (1) kegiatan pelaksanaan pembelajaran yang dilakukan oleh salah seorang guru yang disepakati atau atas permintaan sendiri untuk mempraktikkan RPP yang telah disusun bersama, dan (2) kegiatan pengamatan atau observasi yang dilakukan oleh anggota atau komunitas Lesson Study yang lainnya (baca: guru, kepala sekolah, atau pengawas sekolah, atau undangan lainnya yang bertindak sebagai pengamat/observer).

3. Tahapan Refleksi (Check) 
Tahapan ketiga merupakan tahapan yang sangat penting karena upaya perbaikan proses pembelajaran selanjutnya akan bergantung dari ketajaman analisis para perserta berdasarkan pengamatan terhadap pelaksanaan pembelajaran yang telah dilaksanakan. Kegiatan refleksi dilakukan dalam bentuk diskusi yang diikuti seluruh peserta Lesson Study yang dipandu oleh kepala sekolah atau peserta lainnya yang ditunjuk. Diskusi dimulai dari penyampaian kesan-kesan guru yang telah mempraktikkan pembelajaran, dengan menyampaikan komentar atau kesan umum maupun kesan khusus atas proses pembelajaran yang dilakukannya, misalnya mengenai kesulitan dan permasalahan yang dirasakan dalam menjalankan RPP yang telah disusun.

4. Tahapan Tindak Lanjut (Act)

Dari hasil refleksi dapat diperoleh sejumlah pengetahuan baru atau keputusan-keputusan penting guna perbaikan dan peningkatan proses pembelajaran, baik pada tataran individual, maupun menajerial.

Pada tataran individual, berbagai temuan dan masukan berharga yang disampaikan pada saat diskusi dalam tahapan refleksi (check) tentunya menjadi modal bagi para guru, baik yang bertindak sebagai pengajar maupun observer untuk mengembangkan proses pembelajaran kearah lebih baik.

\section{METODE PENELITIAN}

\section{Jenis data}

Data yang diperoleh adalah berupa informasi dan atau keterangan hasil pengamatan terhadap kemampuan guru dalam melaksanakan kegiatan pembelajaran dengan menggunakan metode Lesson Study.

\section{Analisis Data}

Setelah seluruh data yang diperlukan maka langkah selanjutnya adalah mengolah data dan menganalisis data yang cara-caranya sebagai berikut:

a. Deduksi yaitu upaya memperoleh data yang bersifat khusus melalui penalaran dan penganalisisan data-data yang bersifat umum.

b. Induksi upaya memperoleh data-data yang bersifat umum melalui penalaran dan penganalisasian terhadap data yang bersifat khusus. 
c. Menyandingkan beberapa keterangan atau data yang diperoleh untuk mendapatkan argumentasi yang lebih serta mampu memberikan kejelasan yang layak untuk dijadikan pegangan dalam penelitian.

\section{Subjek Penelitian}

Yang menjadi subjek penelitian adalah guru kelas sebagai berikut :

\begin{tabular}{|c|l|c|c|c|c|}
\hline No & \multicolumn{1}{|c|}{ Nama } & $\begin{array}{c}\text { Pangkat/ } \\
\text { Gol }\end{array}$ & $\begin{array}{c}\text { Jumlah } \\
\text { Jam }\end{array}$ & Kelas & Asal sekolah \\
\hline 1 & Nur Sumarni, S.Pd.AUD & - & 24 & B & $\begin{array}{c}\text { TK } \\
\text { Nurussibyan }\end{array}$ \\
\hline 2 & Dian Nopeta, A.Md & - & 24 & B & $\begin{array}{c}\text { TK } \\
\text { Nurussibyan }\end{array}$ \\
\hline 3 & Rohena, S. Pd. & - & 24 & B & Nurussibyan \\
\hline
\end{tabular}

\section{Prosedur Penelitian}

\section{a. Perencanaan Tindakan}

Perencanaan Tindakan Sekolah dilakukan dengan penilaian terlebih dahulu terhadap kebutuhan-kebutuhan guru yang diperoleh dari informasi hasil pembicaraan dengan guru. Diperoleh kesimpulan bahwa guru memiliki keterbatasan dalam menyusun RPP. Permasalahan ini diangkat menjadi isu pembinaan dengan memberikan penyuluhan tentang penyusunan RPP.

b. Pelaksanaan Tindakan

Setelah dilakukan penilaian terhadap RPP, dilakukan penyuluhan penyusunan RPP sesuai pedoman.

c. Observasi/Pengamatan

RPP yang sudah disusun dilaksanakan dikelas dengan menggunakan instrumen sebagai berikut:

d. Refleksi

Tindakan-tindakan tersebut diimplementasikan dalam tiga siklus tindakan dan setiap siklus diakhiri dengan refleksi. Siklus pertama penilaian RPP menghasilkan penilaian perlunya diberi penyuluhan penyusunan RPP. Siklus 
kedua yaitu melakukan pembinaan melalui tekhnik Lesson Study dan siklus ketiga menghasilkan pembicaraan lebih lanjut tentang supervisi akademik (pembuatan RPP).

\section{Hasil Penelitian dan Pembahasan}

\section{Deskripsi Persiklus}

Pelaksanaan PTS yang direncanakan oleh penulis dalam bentuk pelaksanaan Penelitian Tindakan Kelas dengan judul "Upaya Peningkatan Kinerja Guru Melalui Tekhnik Lesson Study Secara Kolaboratif dan Rutin Di Taman Kanak-kanak Nurussibyan Kota Jambi" berjalan sesuai dengan perencanaan PTS.

Hasil penelitian yang direfleksi dari permasalahan yang menjadi fokus penelitian menunjukan hasil yang membawa pengaruh positif pada guru. Terlihat dari hasil penelitian.

Hasil penilaian dapat terlihat pada tabel di bawah ini:

Rekapitulasi Hasil Penilaian

\begin{tabular}{|c|l|c|c|}
\hline \multirow{2}{*}{ No } & \multicolumn{2}{|c|}{ Nama } & \multicolumn{2}{|c|}{ Nilai Hasil Evaluasi } \\
\cline { 3 - 4 } 1 & Nur Sumarni, S.Pd.AUD & 22 & Siklus II \\
\hline 2 & Dian Nopeta, A.Md & 20 & 31 \\
\hline 3 & ROHENA, S.Pd & 21 & 32 \\
\hline & JUMLAH & 63 & 30 \\
\hline & Rata-rata & 21 & 93 \\
\hline
\end{tabular}


Adapun dalam bentuk diagramnya adalah sebagai berikut:

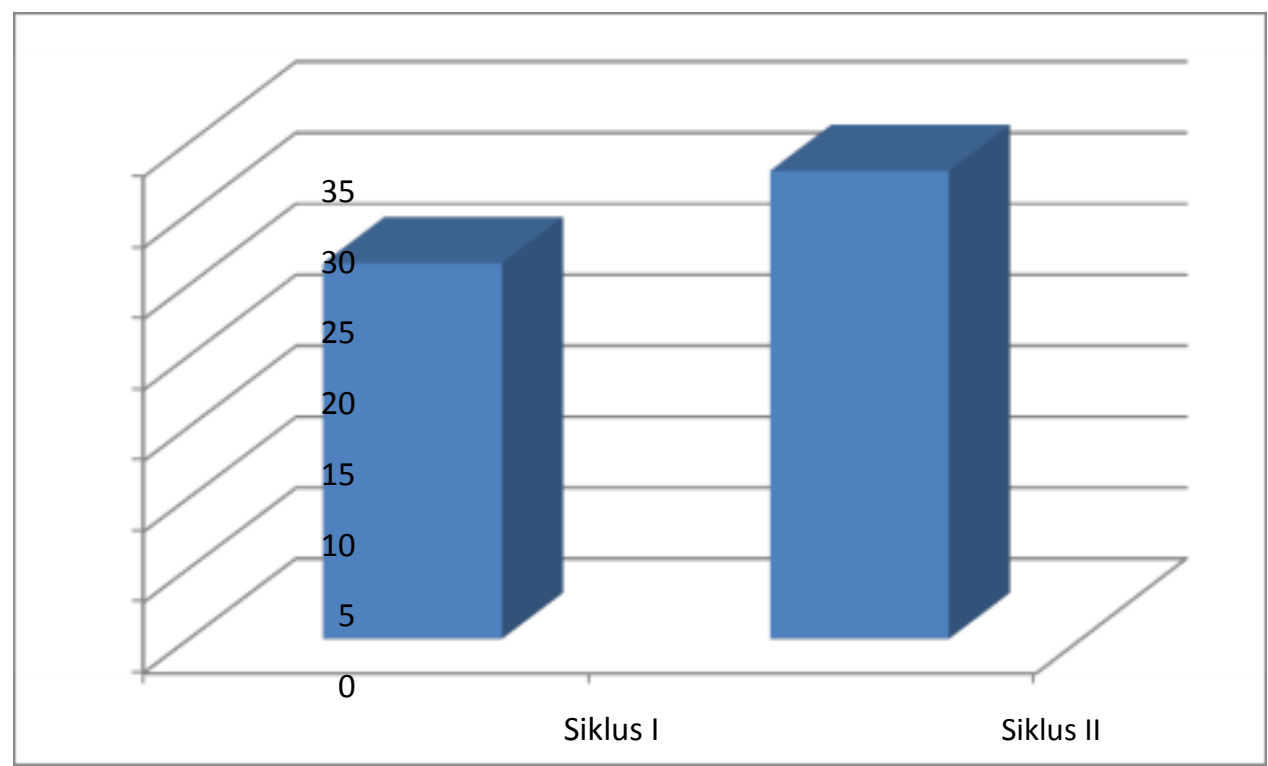

Keterangan :

Penguasaan guru dalam melakukan pembelajaran mengalami peningkatan dari siklus pertama ke siklus kedua setelah diberikan teknik short briefing secara rutin mengenai penyusunan RPP yang benar, materi pelajaran yang akan disampaikan dari siklus ke siklus.

Siklus ke I mencapai rata-rata nilai 21

Siklus ke II mencapai rata-rata nilai 31

Dari 3 guru kelas

Berdasarkan temuan-temuan yang didapat selama mengadakan penelitian terhadap pelaksanaan tugas sehari-hari sebagai kepala sekolah dan penerapan metode Lesson Study secara rutin sebelum guru melakukan tugas mengajar menunjukkan adanya peningkatan produktifitas, profesional dan mutu pembelajaran di kelas.

\section{Pembahasan Tiap Siklus}

Kondisi awal sebelum diterapkan metode Lesson Study secara rutin sebelum guru melakukan tugas mengajar menunjukkan: 
a. Kurangnya kesadaran dan tanggung jawab guru akan tugas pokok dan fungsi yang dibebankan oleh pemerintah.

b. Kurangnya perencanaan yang matang dalam melaksanakan tugas dan belum siapnya guru untuk mengadakan perubahan kearah yang lebih maju sesuai dengan perkembangan dunia pendidikan.

c. Kurangnya pemahaman guru akan tugasnya sebagai agen pembelajaran.

d. Belum terbentuknya disiplin sekolah dan iklim budaya kerja sekolah yang mengacu pada peningkatan mutu pembelajaran.

Pemahaman guru terhadap tugas sebelum diterapkannya pendekatan tersebut adalah dalam melaksanakan tugasnya hanya mengandalkan persiapan seadanya bahkan kadang sama sekali tidak ada persiapan. Hal ini terjadi karena fungsi kontrol sebagai salah satu tugas kepala sekolah tidak berjalan sebagaimana mestinya. Disamping itu seolah-olah guru hanya sekedar melaksanakan tugas tanpa ada perancanaan yang matang dan tidak berpikir bagaimana hasil akhir setelah melaksanakan tugas mengajar. Dapat dibayangkan jika seorang kepala sekolah tidak mempunyai kemampuan untuk mengatur, memimpin, mengelola atau mengadministrasikan sumber daya meliputi perencanaan, pelaksanaan, pengawasan, dan pembinaan terhadap guru-guru sebagai bawahannya.

Teknik Lesson Study dikemas agar menarik, memukau dan apa yang kepala sekolah sampaikan langsung masuk dan dapat diaplikasikan dalam kegiatan pembelajaran oleh guru-guru. Pertama kali yang harus disadari adalah apa yang akan kita sampaikan. Kepala sekolah harus memahami visi sekolah. Visi sekolah akan menurunkan Misi yang sekolah buat dalam waktu yang pendek. Misi yang sekolah buat inilah yang akan menurunkan culture kerja. Culture kerja inilah yang kemudian akan memunculkan Motivasi kerja. Jadi dengan memahami Visi, kepala sekolah akan dapat menciptakan budaya kerja dalam tim sekolah dan sekaligus memunculkan motivasi personil.

Yang kedua, yang harus kepala sekolah sadari bahwa pada saat teknik Lesson Study dimulai, kepala sekolah harus menyadari secara sepenuhnya bahwa teknik ini adalah teknik yang berkesinambungan, yang akan membutuhkan waktu 
untuk bisa beradaptasi dengan teknik baru, maka diperlukan keuletan dan kesabaran dalam mengolah manajemen di sekolah.

Strategi melaksanakan Lesson Study berdasarkan hasil penelitian penulis:

\section{Perencanaan (Plan)}

a. Identifikasi Masalah Pembelajaran

- Materi Ajar

- Kedalaman materi

- Kesesuaian dengan tuntutan kurikulum

- Tingkat kesulitan

b. Strategi Pembelajaran

- Pendahuluan

- Memotivai siswa belajar

- kegiatan inti

c. Penutup

- Aktivitas siswa yang diharapkan untuk menyimpulkan pelajaran

d. Mempersiapkan Perangkat Pembelajaran

- Silabus

- Rencana Pelaksanaan Pembelajaran

- Lembar Kegiatan Siswa

- Alat tes

e. Menentukan Observer

- Kepala Sekolah

- Guru

- Pengawas Sekolah

f. Menentukan Guru Model (pelaksana pembelajaran di kelas)

\section{Pelaksanaan (Do)}

a. Pertemuan singkat (briefing) dipimpin fasilitator (kepala sekolah).

b. Guru model mengemukakan rencana singkat (rencana pembelajaran, tujuan, kedudukan materi ajar dalam kurikulum, perkiraan kemungkinan respon siswa). 
c. Kepala sekolah mengingatkan observer untuk tidak mengintervensi proses belajar mengajar.

d. Observer dipersilahkan memilih tempat strategis sesuai rencana pengamatan.

e. Guru model melaksanakan proses belajar mengajar.

\section{Observasi}

Observer membuat catatan tentang:

- Komentar siswa dalam diskusi.

- Kerja sama siswa.

- Aktivitas belajar.

- Strategi penyelesaian masalah.

Pedoman observer:

a. Kejelasan tujuan pembelajaran.

b. Aktivitas mengarah ke pencapaian tujuan.

c. Langkah-langkah pembelajaran berkaitan mendukung pemahaman siswa.

d. Media pembelajaran mendukung pencapaian tujuan.

e. Diskusi kelas membantu pemahaman konsep.

f. Materi ajar sesuai tingkat kemampuan siswa.

g. Penggunaan pengetahuan awal untuk mendukung pemahaman konsep.

h. Pertanyaan guru mendorong dan memfasilitasi cara berpikir siswa.

i. Pemberian penghargaan gagasan siswa.

j. Kesimpulan didasarkan pendapat siswa.

k. Kesimpulan sesuai tujuan.

1. Pemberian penguatan.

\section{Refleksi (See)}

a. Menentukan fasilitator.

b. Fasilitator mengenalkan observer dengan spesifikasi bidang ilmu.

c. Fasilitator menyampaikan agenda refleksi.

d. Fasilitator menyampaikan aturan main.

- berbicara dengan tertib (jadi pendengar yang baik) 
- berbicara sopan tidak untuk mengadili guru model

- setiap peserta diberi kesempatan berbicara

- berbicara berdasarkan temuan pengamatan

- masukan difokuskan pada "bagaimana siswa belajar"

e. Guru model menyampaikan:

- Kejadian yang sesuai dan yang tidak sesuai dengan harapan.

- Sesuatu yang berubah dari rencana.

- Team pengembang memberi komentar.

- Fasilitator memberi kesempatan observer berkomentar

- Fasilitator mempersilahkan tenaga ahli merangkum diskusi.

- Fasilitator mengucapkan terimakasih dan mengumumkan kegiatan Lesson Study berikutnya.

\section{E. KESIMPULAN DAN SARAN}

\section{a. Kesimpulan}

Berdasarkan pembahasan hasil penelitian yang telah dilakukan dalam bab sebelumnya melalui "Upaya Peningkatan Kinerja Guru Melalui Teknik Lesson Study Secara Kolaboratif dan Rutin Di Taman Kanak-kanak Nurussibyan Kota Jambi" dapat ditarik kesimpulan, sebagai berikut:

1. Pelaksanaan program yang rutin dan berkesinambungan merupakan kunci keberhasilan dalam melaksanakan tugas sebagai kepala sekolah dalam meningkatkan mutu pembelajaran di kelas.

2. Pada "Upaya Peningkatan Kinerja Guru Melalui Teknik Lesson Study Secara Kolaboratif dan Rutin Di Taman Kanak-kanak Nurussibyan Kota Jambi" ternyata mampu membentuk tenaga pendidik yang produktif/ profesional dan mampu meningkatkan mutu pembelajaran.

3. Dengan adanya terobosan dan inovasi melalui pendekatan "Upaya Peningkatan Kinerja Guru Melalui Teknik Lesson Study Secara Kolaboratif dan Rutin Di Taman Kanak-kanak Nurussibyan Kota Jambi " ternyata ada pengaruh yang besar terhadap hasil belajar siswa. 
Dengan demikian "Upaya Peningkatan Kinerja Guru Melalui Teknik Lesson Study Secara Kolaboratif dan Rutin Di Taman Kanak-kanak Nurussibyan Kota Jambi " ternyata dapat meningkatkan mutu pembelajaran di kelas di TK NURUSSIBYAN UPTD Pendidikan Kecamatan Jambi Selatan Kota Jambi.

\section{Saran}

Berdasarkan kesimpulan di atas, guru dituntut untuk melaksanakan beberapa hal dalam meningkatkan kualitas pembelajaran, khususnya dalam meningkatan penguasaan materi pelajaran dan keaktifan siswa dalam belajar.

Adapun hal-hal yang harus dilakukan guru diantaranya :

- Menentukan tujuan pembelajaran (lesson) satuan (unit) pelajaran, dan mata pelajaran yang efektif.

- Mengkaji dan meningkatkan pelajaran yang bermanfaat bagi siswa.

- Memperdalam pengetahuan tentang mata pelajaran yang disajikan para guru.

- Menentukan tujuan jangka panjang yang akan dicapai para siswa.

- Menentukan pelajaran secara kolaboratif.

- Mengkaji secara teliti belajar dan perilaku siswa.

- Mengembangkan pengetahuan pembelajaran yang dapat diandalkan.

- Melakukan refleksi terhadap pengajaran yang dilaksanakannya berdasarkan pandangan siswa dan koleganya.

\section{DAFTAR PUSTAKA}

Hendayana S. 2006. Lesson Study Suatu Strategi untuk Meningkatkan Keprofesionalan Guru (Pengalaman JUSTEP-JICA). Bandung: UPI Press.

Parmin dan Siti Aminah. 2008. Menerapkan Lesson Study Dalam Pembelajaran di MI Madariful Huda Pati. Laporan Penelitian Dosen Muda. FMIPA: Universitas Negeri Semarang.

Widhiartha, Putu Ashintya. Dwi Sudarmanto. Nining Ratnasingsih. 2008. Lesson Study Sebuah Upaya Peningkatan Mutu Pendidik Pendidikan Non Formal. Surabaya: Prima Printing. 
Yusak, Muchlas. 2008. Lesson Study: Pengembangan

Profesi

GuruSecara Berkelanjutan Berbasis Sekolah. Semarang: LPMP Jawa Tengah.

http://www.slideshare.net/aminhers/lesson-study, Lesson Study-Presentation Transcript, 2010 